\title{
Contribution of Expatriates in the Management of Subsidiaries to the Corporate Governance of International Firms: the Case of Vale ${ }^{(1)}$
}

\author{
T. Diana L. van Aduard de Macedo-Soares * \\ E-mail address: redes@strategy-research.com \\ IAG/Pontifícia Universidade Católica do Rio de Janeiro \\ Rio de Janeiro, RJ, Brazil.
}

\section{Adriana Maria Gutierrez Schubsky}

E-mail address: Adriana.gutierrez@vale.com

Vale S.A

Rio de Janeiro, RJ, Brazil.

\begin{abstract}
In the current context of globalization, where firms are increasingly operating in networks of relationships with international subsidiaries, the relevance of their corporate governance has become evident. By the same token, the contribution to corporate governance of expatriates in these subsidiaries has become an important topic of discussion. The literature is not unanimous in recognizing the contribution of expatriates. However, the question as to whether the participation of expatriates in the management of international firms' subsidiaries is a critical success factor for their corporate governance has not been fully analyzed. This article presents the results of a study of a leading international firm - Vale - that investigated this question from a network perspective, with a view to narrowing this gap. The case study method was adopted and data collected from various sources documental investigation, structured questionnaires and interviews. The results suggested that expatriates can contribute to the success of corporate governance, especially through informal elements pertinent to social mechanisms of governance, such as commitment, communication, flexibility, trust and interdependence. The study thus provided insights for both managers of international firms and academics on corporate governance from a network perspective.
\end{abstract}

Key words: corporate governance; international management; expatriates; network organizations.

Received 01 October 2008; received in revised form 17 June 2009.

Copyright (C) 2010 Brazilian Administration Review. All rights reserved, including rights for translation. Parts of this work may be quoted without prior knowledge on the condition that the source is identified.

* Corresponding author: T. Diana L. van Aduard de Macedo-Soares

PUC-Rio/ IAG, Rua Marquês de São Vicente, 225, Gávea, Rio de Janeiro, RJ, 22453-900, Brazil. 


\section{INTRODUCTION}

In order to meet the increasing needs of customers and thus sustain a competitive advantage in the current context of globalization, international firms, in most sectors, are joining forces and operating in networks of relationships with other firms, including their own subsidiaries. Their success thus depends, in part, on harmonizing the interests of firms subject to different legislations, market practices and cultures. Given the challenge and complexity of managing these networks (Strikwerda, 2003), the importance of corporate governance in the promotion of transparent and healthy international relationships has become evident. This has sparked a debate regarding the contribution of expatriate subsidiary managers to the corporate governance of international firms. The literature is not unanimous in recognizing their contribution (Bjorkman, 2004; Volkmar, 2003). However, the role of expatriates, especially where corporate governance is concerned, has not as yet been fully investigated or empirically tested (Minbaeva \& Michailova, 2004; Riusala \& Suutari, 2004).

In order to help narrow this gap, we carried out a study at the leading iron ore company, Vale, in an attempt to answer the following research question: Is the participation of Vale's expatriates in the management of its international subsidiaries a critical success factor for its corporate governance?

The purpose of this article is to present the most relevant results of this study that was undertaken from a network perspective and whose specific objectives were to verify whether expatriate managers of Vale's international subsidiaries indeed contribute to the success of its corporate governance, and how they do so. It is hoped that the article can provide some valuable insights for both academia and managers concerned with the corporate governance of international firms and role of their expatriates.

Vale is a world leader in its sector and has been undergoing a vigorous internationalization process, leading it to establish several wholly owned subsidiaries organized into a network of relationships with the parent company (Companhia Vale do Rio Doce [CVRD], 2005, 2009). It was thus assumed that it had advanced managerial network practices that could also be of interest to firms with international subsidiaries in other sectors.

Scientific studies usually analyze the expatriation theme from the perspective of human resources management (Bueno, 2004). Although recognizing that the latter is important for expatriates' performance, our study attempted to add value by concentrating on corporate governance as a fundamental construct of network management. Note that we focused on Vale's wholly owned international subsidiaries that were in operation in 2006 and its network of relationships with them at that time.

The article is divided into four parts, in addition to this introduction. The first and second parts explain the theoretical references and research methodology. The third presents the study's main results and discusses the extent to which its suppositions are confirmed. The last part assesses the study's contributions and makes suggestions for future research.

\section{THEORETICAL REFERENCES}

First of all, it should be emphasized that we assumed that the relationships between a parent company and its wholly owned international subsidiaries could be analyzed using the strategic network concept. Indeed, the study aimed at contributing to a better understanding of expatriates' role in ensuring the success of corporate governance, by adopting a network approach, i.e., taking into account the positive and negative strategic implications of the company's network of relationships with its subsidiaries, considering the network's characteristics. 


\section{Literature Review and Definitions}

To define the network concept, most studies, especially those concerning multinational firms (Lü, 2001), have adopted an inter-organizational perspective. Their object has generally been the relationships established between multinational firms and their international partners (suppliers, customers, competitors, etc.). Our study, however, was undertaken from an intra-organizational perspective (Lü, 2001), where the parent company is the focal firm, and its object is the network of relationships between the parent company and its wholly owned international subsidiaries, assuming that the latter have a degree of autonomy similar to that enjoyed by other international partners.

This view of multinational corporations as a network of intra-organizational relationships is not entirely new. Our contribution is to adopt inter-organizational network constructs to carry out a strategic network analysis at an intra-organizational level. We assume that we can thus gain insights that could not be found by way of the traditional intra-organizational network analysis.

The concept of strategic network draws on that of Gulati, Nohria and Zaheer (2000), but its scope is broadened by adding the intra-organizational dimension for the specific case of the relationships between the parent firm and its wholly owned subsidiaries. Because it includes the relationships between legally distinct entities that enjoy a certain degree of autonomy and analyzes these relationships from a strategic network perspective, the research considered that it would be possible to use Macedo-Soares's (2002) Strategic Network Analysis [SNA] model. This model has indeed been applied with success to many types of firms embedded in networks (Macedo-Soares \& Figueira, 2007; Macedo-Soares, Tauhata, \& Freitas, 2004; Macedo-Soares, Tauhata, \& Lima, 2005). It was only necessary to adapt the model in order to also contemplate specific intra-organizational network variables.

The definition of strategic network was also reformulated by us as follows: a firm's strategic network is composed of its relationships - horizontal and vertical - with other organizations, whether they are suppliers, customers, competitors, subsidiaries or other entities. These relationships are composed of intra-organizational - in the specific case of networks between a firm and its subsidiaries that show a degree of relative autonomy - or resistant inter-organizational ties, ... that are strategically important to the member firm (Gulati, Nohria, \& Zaheer, 2000).

It should be added that, drawing on Gao, Bao and Wang's (2002) definition of international strategic alliances, international strategic networks were defined as those that provide opportunities for obtaining international competitive advantages.

A broad definition was also adopted for corporate governance, drawing on Cornelius and Kogut (as cited in Cornelius, 2005, p. 13) which included both formal and social corporate governance mechanisms:

the system constituted by the institutions, laws, values and formal and informal rules, that produce the different legal and organizational forms found in a country and which in turn, determine the distribution of powers - how authority is designated, management decisions taken and monitored, how information is audited and published, and profits and benefits allocated and distributed.

Kauser and Shaw (2004) observed that behavioral characteristics have a greater impact on the performance of international strategic relationships than organizational characteristics. Characteristics such as commitment, interdependence, coordination and communication are seen to be factors that make success possible, whereas characteristics such as structure and control mechanisms appear not to be determining factors in the success of such relationships. In a complementary fashion, Bachmann (2001) analyzed trust and power as trans-organizational alliance coordination mechanisms. In addition, Costa (2007) discussed the trust and control relationship as complementary mechanisms for the governance of organizational relations, and presented key implications for theory building on the subject. 
In line with the views of Bachmann (2001) and Kauser and Shaw (2004), Moraes (2005) identified five variables associated with social corporate governance mechanisms from a network perspective: commitment, communication, flexibility, trust and interdependence. Moraes also analyzed the power variable associated with formal corporate governance mechanisms. His study was restricted to a single country and therefore did not contemplate variables for international firms.

In our research, we drew on Bueno (2004), Clarke and Lipp (1998), Meschi (1997) and Rodriguez (2005) to include tools of cultural integration as a variable that is pertinent to social corporate governance mechanisms for networks in an international context.

Several factors motivate the participation of expatriates in the management of the international units of multinational firms. In their seminal work, Edström and Galbraith (1977) identified three motivating factors: i) transfer of technical knowledge to a developing country; ii) managerial development of the expatriate executive; iii) a strategy to coordinate and control the subsidiary. With respect to headquarters-subsidiary knowledge transfer of international firms, Lee and MacMillan (2008) found that coordinative knowledge-sharing was positively associated with subsidiary performance.

Boyacigiller (1990) analyzed motivating factors based on subsidiary characteristics that influence an international appointment: a) the political risk of the country where the subsidiary is located; b) the subsidiary's complexity; c) the cultural distance between the parent company's country and that of the subsidiary; d) the interdependence between the parent company and subsidiaries.

In connection with the importance of taking into account the subsidiary's characteristics, Kim, Prescott and Kim (2005) examined the effects of agency problems in the headquarters-subsidiary relationships on corporate governance design in transnational corporations. They argued that the corporate governance of foreign subsidiaries in such corporations should be constructed in response to different levels of agency problems according to the subsidiaries' varying strategic roles.

Based on documental research, it was observed that Vale expatriates its employees when the country in which its subsidiary is located does not have people with the necessary technical and managerial competences required for key positions, or when appropriate conditions for the development of skills are absent (CVRD, 2005).

Note that various definitions of the term expatriate were identified in the literature. As we focused on Vale, we adopted the definition used by this company, according to which an expatriate is an employee who is transferred to another country for a period of more than 3 months.

As already mentioned, there is virtually no consensus in the literature regarding the contribution of expatriate subsidiary managers to the corporate governance of international firms.

Some studies analyze the participation of expatriates in the strategic management of firms from the point of view of the exchange of knowledge and information, cultural integration (Clarke \& Lipp, 1998; Meschi, 1997), and the transmission of the values, rules and regulations of their unit of origin (Edström \& Galbraith, 1977; Minbaeva \& Michailova, 2004; Riusala \& Suutari, 2004).

More wide-ranging studies relate the interchange of knowledge to accountability, to conduct standardization and to transparency and control of the international relationship (Boyacigiller, 1990; Fenwick, De Cieri, \& Welch, 1999; Harzing, 2001). To some extent, these studies also analyze the participation of expatriates in the management of international units from the point of view of corporate governance of the parent company's relationships with these units. Our study adopted a similar approach. 


\section{Assumptions}

The study was based on the following assumptions: (A1) the Vale parent company and its wholly owned international subsidiaries form an international strategic network; (A2) the network can be governed using both formal and social mechanisms; (A3) researchers in strategic management have identified indicators to measure the use of formal and social corporate governance mechanisms; (A4) the corporate governance of networks of international relationships is a critical success factor for the effective management of these networks; (A5) the perceptions of the firm's executives are a valid source of strategic information because they play a significant role in strategic management (Kotha \& Vadlamani, 1995).

\section{Suppositions}

On the basis of the theoretical references of the research, and in order to answer its central question, we formulated the following 3 suppositions:

(S1) the participation of expatriates in the management of Vale's international subsidiaries can be a critical success factor for the corporate governance of the company's network of relationships with these subsidiaries to the extent that they contribute informal elements pertinent to social mechanisms of corporate governance;

(S2) the Vale parent company perceives that it benefits from the participation of expatriates in the management of its international subsidiaries due to their contribution to the corporate governance of the parent company $\rightarrow$ subsidiary relationship;

(S3) the international subsidiaries also perceive that they benefit from the participation of the Vale parent company's expatriates in their management due to their contribution to the corporate governance of the subsidiary $\rightarrow$ parent company relationship.

\section{Conceptual Tools}

The model of strategic analysis adopted in this study is the SNA Model. Although this model does not contemplate intra-organizational networks, it was deemed adequate following some adaptations, beginning with a broadened definition of the strategic network (see Section Literature Review and Definitions).

Drawing mainly on Galaskiewicz and Zaheer (1999), and Gulati et al. (2000), the SNA model includes two reference lists with constructs for carrying out strategic analyses at both industry and firm levels from a network perspective. Three dimensions are used at both levels: (1) Network Structure - Centrality of parent firm: high centrality in the network has positive implications (Zaheer \& Zaheer, 1997 as cited in Gulati et al.), (2) Network composition - Identity and Status of parent firm and subsidiaries: high status has positive implications, (3) Nature of Ties - Strength which has positive implications inasmuch as it can contribute to the inimitability of positive relational characteristics (Dyer \& Nobeoka as cited in Gulati et al., 2000). A fourth dimension is considered at the firm level: (4) Network Management which includes the governance construct. This dimension is therefore focused on in this study. However, information regarding the other two dimensions is taken into account.

Based in part on the corporate governance variables used by Moraes (2005), which in turn drew on the SNA model, our study proposed a new list of variables and indicators pertinent to formal and social corporate governance mechanisms (see Table 1). 
Table 1

Variables and Indicators for Corporate Governance

\begin{tabular}{|c|c|c|}
\hline Variables & Indicators & Sub-indicators \\
\hline Power & $\begin{array}{l}\text { Non-coercive/ } \\
\text { Coercive }\end{array}$ & $\begin{array}{l}\text { - Punishment/penalization Inability/ Ability (Bachmann, 2001; Dickson \& } \\
\text { Zhang, 2004) } \\
\text { - Inability/ Ability to threaten (Dickson \& Zhang, 2004) } \\
\text { - Existence/ Non-existence of power through assistance: power establishec } \\
\text { through dependence on the more powerful partner (Dickson \& Zhang } \\
\text { 2004) } \\
\text { - Existence/ } \frac{\text { Non-existence of power through reward from the partnership }}{\text { (Dickson \& Zhang, 2004) }}\end{array}$ \\
\hline $\begin{array}{l}\text { Commitment } \\
\text { Collaborative } \\
\text { And Ethical } \\
\text { Behavior }\end{array}$ & $\begin{array}{l}\text { Collaborative } \\
\underline{\text { Opportunistic }}\end{array}$ & $\begin{array}{l}\text { - Desire/ Lack of desire to maintain a relationship (Bantham, Celuch, \& } \\
\text { Kasouf, 2003; Hunt \& Morgan, 1994) } \\
\text { - Non-existence/Existence of the option to change a partner (Bantham et } \\
\text { al., 2003) }\end{array}$ \\
\hline $\begin{array}{l}\text { Communi- } \\
\text { cation }\end{array}$ & $\begin{array}{l}\text { Frank/ } \\
\text { Non-existent }\end{array}$ & $\begin{array}{l}\text { - Clear/ Ambiguous communication (Wagner, Macbeth, \& Boddy, 2002) } \\
\text { - Regular/ Irregular communication between partners is frequent (Wagner et } \\
\text { al., 2002) } \\
\text { - Existence/ Non-existence of formal meetings to share information and } \\
\text { knowledge (Wagner et al., 2002) }\end{array}$ \\
\hline
\end{tabular}

Awareness/ Lack of awareness of information concerning a partner (Wagner et al., 2002)

Flexibility Flexible/

$\underline{\text { Rigid }}$

Trust

Existent/

$\underline{\text { Non-existent }}$

Interdepen- Recognized/ dence
- Ability/ Inability to adjust behavior on the part of the partner (Heide \& Miner, 1992)

- Agility/ Lack of agility to respond rapidly to changes (Prater, Biehl, \& Smith, 2001)

- Low/ High cost of change associated with agility of response and capacity to adapt to new conditions (e.g. shipping by air is quicker but more expensive than by sea) (Prater et al., 2001)

Existence/ Non-existence of case-by-case decisions - in the case of extreme rigidity, pre-established formal rules hold and decisions are never taken on a case-by-case basis (Segil, 1998)

- Expectation that a partner will/will not act opportunistically, even though such behavior would certainly provide him with benefits in the short term and perhaps also in the long term (Chiles \& McMackin, 1996; Hunt \& Morgan, 1994)

- Partner's solid/weak reputation for trustworthiness (Chiles \& McMackin, 1996)

- Moderate / excessive heeding of contractual rules reflecting lack of trust (Chiles \& McMackin, 1996)

Perception of a low/ high risk that agreements will not be fulfilled (Bachmann, 2001)

- Perception of the importance/ insignificance of a partner for the firm's own success (Moraes, 2005)

Impossibility/ Possibility of quickly changing a partner (Heide \& Miner, 1992) 
Table 1 (continued)

\begin{tabular}{lcc}
\hline \multicolumn{1}{c}{ Variables } & Indicators & \multicolumn{1}{c}{ Sub-indicators } \\
\hline $\begin{array}{l}\text { Cultural } \\
\text { integration }\end{array}$ & High/ & $\begin{array}{l}\text { L Ex } \\
\text { Existence/ Non-existence of mapping and control of cultural } \\
\text { differences (Meschi, 1997) } \\
\text { - Non-occurrence/ } \text { Occurrence of conflicts caused by cultural } \\
\text { differences (Meschi, 1997) }\end{array}$ \\
\hline
\end{tabular}

Note. (N.B. Indicators with positive implications are in bold type and those with negative implications in italics).

The following may be highlighted among the differences introduced in relation to Moraes' version (2005): (i) definition of sub-indicators in order to assess better the indicator's implications; (ii) adaptation to the intra-organizational nature of the relationships of the network under analysis; (v) addition of the cultural integration variable because of its importance to international firms.

\section{ReseARCH Methodology}

\section{Choice of Methods and Design}

In keeping with its specific objectives, our research was predominantly descriptive, with some exploratory characteristics; it was conducted using the case study method which, given their complexity, was considered an appropriate means of investigating networks (Halinen \& Törnroos, 2005).

This method is usually chosen when the purpose of the research is to understand how a contemporary phenomenon occurs in the light of its specific contingencies of the context (Patton, 1987; Yin, 2003). However, as Yin observed, "the case study is an umbrella term ...; different orientations and approaches may fall within its domain" (p. 51). He gives the example of a dissertation that adopted this method to understand the interrelationships between a group's corporate strategy and the strategies of the independent subsidiaries in the group, noting that although a variety of evidence was collected, the focus of the analytical work was on quantitative issues that employed statistical packages.

To some extent, we adopted the same focus in our study at Vale. The main objective was to obtain data and information in order to verify the suppositions, but not to attempt to analyze it in the light of the specific contingencies of the parent company and each one of its 12 subsidiaries. This was beyond the scope of the study's objectives, for which it was not deemed necessary to enter into the level of detail regarding the subsidiaries that would be required for a deeper analysis. Most of the background information collected was therefore limited to relevant characteristics of the network investigated, according to the main SNA dimensions.

To ensure the reliability and reproducibility of the study, we established a protocol with a statement of its objectives and a plan indicating how these were to be achieved. In this plan, the theoretical references and the study's 3 main suppositions were fundamental for defining field procedures and issues. Indeed, the SNA general constructs, as well as a detailed list of variables for network corporate governance (Table 1) formed the basis for developing the data collection instruments and establishing data treatment methods. These are detailed below. The two protocol issues that reflect the study's main concerns were: i) evaluation of the network of relationships between the Vale parent company and its international subsidiaries; ii) participation of expatriates in the management of Vale's international subsidiaries. 


\section{Data Collection}

The following methods were adopted in accordance with the method triangulation strategy recommended by Patton (1987) and Yin (2003): documental/telematic investigations, questionnaires and follow-up interviews to capture executives' perceptions. The objective of this strategy is, when applicable, to triangulate, in the sense of confronting and comparing data collected through different means and sources and retaining only the most consistent one, "following a corroboratory mode" (Yin, 2003, p. 92) in order to ensure greater reliability and accuracy of the results.

The questionnaire was divided into two parts, in keeping with the main protocol issues, and structured according to Likert scales (1-5; 1-3). First the questionnaire was tested with representative members of the study's population to assess its clarity and reliability. After making adjustments on the basis of this test, it was sent by e-mail to the expatriate and local managers that took part in the study. In order to preserve the latter's confidentiality, the data is presented in its consolidated form and the contents of the interviews used to cross-check the questionnaires' results are not included in this article.

\section{Universe and Population}

The universe of wholly-owned subsidiaries focused on in the study was selected according to three criteria: (1) it was located abroad (in relation to the parent company); (2) it had management-level expatriates that had been sent by the parent company; (3) it had local managers that had not been previously employed by the parent company.

Therefore, the following 12 subsidiaries of Vale were chosen: CVRD International S.A. [CVRDi], RD Manganèse Europe [RDME], DOCENAVE Argentina S.R.L. [Docenave Argentina], Compañia Minera Miski Mayo S.A.C. [Miski Mayo], CVRD Venezuela S.A. [CVRD Venezuela], RD Australia Pty Ltd [RD Australia], RD Asia Shangai, RD Asia Tokyo, Tethys Mining LLC [TETHYS], RD South Africa (Proprietary) Limited (RDSA), RD Moçambique Ltda [RDMZ], Compagnie Minière Trois Rivières [CMTR] and Compañia Minera Latino Americana Ltda [CMLA].

This universe of companies contained a total of 68 expatriates and 391 local employees (November, 2006), with 49 expatriates and 42 local employees holding management positions. Expatriate and local employees were treated as separate populations. The minimum necessary response rate was calculated in accordance with Rea and Parker's (1997) formula for small populations, and after establishing a confidence interval of $95 \%$, with a margin of error of $\pm 10 \%$. Thus, a response rate of 25 expatriate and 21 local managers was found to be sufficient. In reality, the response exceeded these numbers: 30 expatriate managers and 24 local managers returned completed questionnaires.

\section{Data Treatment}

The data collected through the questionnaires were treated statistically in order to calculate each question's sample averages for expatriate and local managers, respectively. These averages were compared, using the statistical analysis of variance method [ANOVA] (McClave, Benson, \& Sincich, 2001). For questions where there was no evidence of population variance equality, the latter was replaced by the Kruskal-Wallis (McClave et al., 2001) non-parametric test.

In the case of the interviews, content analysis techniques (categorizations of subjective information based on frequency of occurrence) were used to carry out the necessary inferences (Weber, 1990). 


\section{RESULTS AND DISCUSSION}

\section{Results}

As can be observed in Table 2, the results of the first part of the questionnaire strongly suggest that the participation of the Vale parent company in the network of relationships with its international subsidiaries was perceived by managers in these subsidiaries as a fundamental part of its strategy (see Question - Q 1, Expat Av. 4.3; Loc. Av. 3.8 on Max 5 Likert scale). This result is significant because it provides support for the assumption that what is at issue in the study is indeed a strategic network and that the Vale parent company is viewed as having a strategic role in this network.

Table 2

Statistical Results of the $1^{\text {st }}$ Part of the Questionnaire

\begin{tabular}{|c|c|c|c|c|c|c|}
\hline Question & $\begin{array}{l}\text { Construct based } \\
\text { on the SNA model }\end{array}$ & $\begin{array}{c}\text { Max. } \\
\text { Likert } \\
\text { Scale }\end{array}$ & $\begin{array}{l}\text { Expat } \\
\text { Aver. }\end{array}$ & $\begin{array}{l}\text { Local } \\
\text { Aver. }\end{array}$ & p-value & High-est \\
\hline $\begin{array}{l}1 \text { - Does participation of the Vale } \\
\text { parent company in the network of } \\
\text { relationships with its international } \\
\text { subsidiaries constitute a fundamental } \\
\text { part of its strategy? }\end{array}$ & - & 5 & 4.3 & 3.8 & 0.034 & Expat \\
\hline $\begin{array}{l}2 \text {-Evaluate the strength of } \\
\text { connections between Vale and its } \\
\text { international subsidiaries. }\end{array}$ & $\begin{array}{l}\text { Strength of } \\
\text { connections }\end{array}$ & 3 & 2.5 & 2.3 & 0.301 & - \\
\hline $\begin{array}{l}3 \text { - Evaluate Vale's position of } \\
\text { centrality in its network of } \\
\text { relationships with its international } \\
\text { subsidiaries. }\end{array}$ & Centrality position & 3 & 2.7 & 2.5 & 0.433 & - \\
\hline $\begin{array}{l}4 \text { - Incentives to the Vale parent } \\
\text { company's internationalization process } \\
\text { provided by governmental authorities. }\end{array}$ & $\begin{array}{l}\text { Government } \\
\text { incentives for its } \\
\text { internationaliza- } \\
\text { tion process }\end{array}$ & 3 & 1.5 & $1.6^{*}$ & 0.706 & - \\
\hline $\begin{array}{l}5 \text { - Investments made by Vale parent } \\
\text { company in its subsidiaries. }\end{array}$ & $\begin{array}{l}\text { Making of invest- } \\
\text { ments by parent } \\
\text { company in subsi- } \\
\text { diary relationships }\end{array}$ & 3 & 2.1 & 1.9 & 0.116 & - \\
\hline $\begin{array}{l}6 \text { - Comparison of Vale parent } \\
\text { company with its competitors } \\
\text { regarding relationships with } \\
\text { international subsidiaries. }\end{array}$ & - & 3 & 1.8 & 1.4 & 0.044 & Expat \\
\hline $\begin{array}{l}7 \text { - Level of interna-tional } \\
\text { subsidiaries' delegation of authority. }\end{array}$ & $\begin{array}{l}\text { Level of } \\
\text { decentralization via } \\
\text { authority } \\
\text { delegation }\end{array}$ & 3 & 1.4 & 1.3 & 0.409 & - \\
\hline $\begin{array}{l}8 \text { - Use of most modern corporate } \\
\text { governance practices }\end{array}$ & $\begin{array}{l}\text { Use of governance } \\
\text { mechanisms }\end{array}$ & 5 & 3.4 & 2.8 & 0.028 & Expat \\
\hline
\end{tabular}

Note. * This result was not considered valid, as $79 \%$ of local employees did not reply to this question.

N.B. For questions of the first part, the standard deviation showed a value equal to or lower than 1.0. 
The latter is corroborated by the positive result regarding the question on Vale's position of centrality in this network (Q. 3, Expat Av. 2.7; Loc. Av. 2.5 on Max 3 Likert). As a network structure attribute, we saw that, in the literature, high centrality is considered to have positive implications for network management. These implications are enhanced when the relationships of the network are of significant strength, as in the case of Vale, according to the results of Question 3 (Expat. Av. 2.5; Loc. Av. 2.3 for Max 3 Likert).

Investments by the Vale parent company in its international subsidiaries are also an indicator of its strategic role in the relationships with them and of the strength of connections. The results of this question were also quite positive (Q. 5, Expat Av. 2.1; Loc. Av. 1.9 - Max 3 Likert), although not to the same extent as in the case of the other three questions.

Among the other results in the first part of the questionnaire, the only really significant ones were those concerning the use of modern corporate governance practices. As shown in Table 2 (see Q. 8, Expat Av. 3.4; Local Av. 2.8 - Max 5 Likert), the results for this question were also fairly positive. Earlier we mentioned that we chose Vale for the study because it was an international leader in its sector and, therefore, presumably employed advanced managerial practices. These results lend support to our point precisely in the category of practices - corporate governance - focused on in the study.

The results of the other questions in this first part of the questionnaire were not considered conclusive, even after an attempt to obtain more information through the interviews. Note that, generally speaking, the results in this first part suggested a convergence between the perceptions of expatriate and local managers for most questions; only replies to Questions 1, 6 and 8 indicated a difference in sample averages, with a higher average for the expatriates.

Table 3

Statistical Results of the 2nd part of the Questionnaire

\begin{tabular}{|c|c|c|c|c|c|}
\hline Variables & Questionnaire Question & $\begin{array}{l}\text { Expat } \\
\text { Aver. }\end{array}$ & $\begin{array}{l}\text { Local } \\
\text { Aver. }\end{array}$ & p-value & Highes \\
\hline \multirow[t]{2}{*}{ Power } & $\begin{array}{l}13 \text { - Communication with the Vale parent } \\
\text { company is conducted solely via expatriates }\end{array}$ & 2.6 & 2.6 & 0.959 & - \\
\hline & $\begin{array}{l}31 \text { - The local employees of the international } \\
\text { subsidiary are implicitly or explicitly supervised } \\
\text { by expatriates }\end{array}$ & 3.4 & 3.0 & 0.120 & - \\
\hline \multirow[t]{3}{*}{ Commitment } & $\begin{array}{l}14 \text { - Expatriates seek to establish enduring } \\
\text { professional relationships with local employees }\end{array}$ & 3.5 & 3.1 & 0.230 & - \\
\hline & $\begin{array}{l}15 \text { - Local employees seek to establish enduring } \\
\text { professional relationships with expatriates }\end{array}$ & 3.5 & 3.5 & 0.981 & - \\
\hline & $\begin{array}{l}16-\text { Expatriates pay attention to the specific } \\
\text { needs of the international subsidiary }\end{array}$ & 4.2 & 3.8 & 0.069 & - \\
\hline \multirow[t]{4}{*}{ Communication } & $\begin{array}{l}9 \text { - Communications between the Vale parent } \\
\text { company and international subsidiaries are } \\
\text { frequent }\end{array}$ & 3.1 & 3.5 & 0.280 & - \\
\hline & $\begin{array}{l}10 \text { - Expatriates frequently transmit information } \\
\text { and guidelines from Vale parent company }\end{array}$ & 4.1 & 3.3 & $0.042 *$ & Expat \\
\hline & $\begin{array}{l}11 \text { - Expatriates transmit information and } \\
\text { guidelines in a clear and transparent way }\end{array}$ & 3.8 & 3.0 & $0.012 *$ & Expat \\
\hline & $\begin{array}{l}12 \text { - Expatriates organize meetings about the } \\
\text { Vale parent company }\end{array}$ & 3.7 & 3.1 & 0.058 & - \\
\hline
\end{tabular}


Table 3 (continued)

\begin{tabular}{|c|c|c|c|c|c|}
\hline Variables & Questionnaire Question & $\begin{array}{l}\text { Expat } \\
\text { Aver. }\end{array}$ & $\begin{array}{l}\text { Local } \\
\text { Aver. }\end{array}$ & p-value & Highest \\
\hline \multirow[t]{4}{*}{ Flexibility } & $\begin{array}{l}17 \text { - In the international subsidiary, all } \\
\text { important decisions require the Vale parent } \\
\text { company's approval }\end{array}$ & 4.1 & 3.8 & 0.268 & - \\
\hline & $\begin{array}{l}18 \text { - Decisions that require the Vale parent } \\
\text { company's approval are taken in an agile } \\
\text { manner }\end{array}$ & 2.6 & 2.5 & 0.551 & - \\
\hline & $\begin{array}{l}19 \text { - In the international subsidiary, all } \\
\text { important decisions require expatriate approval }\end{array}$ & 3.9 & 3.6 & 0.313 & - \\
\hline & $\begin{array}{l}20 \text { - All important decisions that require } \\
\text { expatriate approval are taken in an agile manner }\end{array}$ & 3.6 & 3.4 & 0.443 & - \\
\hline \multirow{4}{*}{ Trust } & $\begin{array}{l}21 \text { - Decisions taken by expatriates are not } \\
\text { negotiable }\end{array}$ & 2.4 & 2.8 & 0.157 & - \\
\hline & $\begin{array}{l}28 \text { - There is a high risk that the Vale parent } \\
\text { company will not fulfill agreements with an } \\
\text { international subsidiary }\end{array}$ & 2.0 & 2.7 & 0.013 & Local \\
\hline & $\begin{array}{l}29 \text { - There is a high risk that expatriates will not } \\
\text { fulfill agreements with local employees }\end{array}$ & 1.9 & 2.6 & 0.003 & Local \\
\hline & $\begin{array}{l}30 \text { - There is a risk that expatriates will act } \\
\text { opportunistically }\end{array}$ & 1.9 & 2.8 & 0.001 & Local \\
\hline
\end{tabular}

Note. * Kruskal-Wallis Test. Note: For all the questions of the second part of the questionnaire, the standard deviation showed a value equal to or less than 1.4.

The statistical results of the second part of the questionnaire are presented in Table 3. We analyze these results below, beginning with the formal power corporate governance variable. Note that the format in this part was a Maximum 5 Likert scale.

i) In the case of the power variable, the results were not conclusive. On the one hand, the respondents perceived that the local employees were to a certain extent supervised by expatriates (Q. 31, Expat Av. 3.4; Local Av. 3.0). On the other hand, when asked whether communication with the Vale parent company was performed solely via expatriates, the replies were neutral $(\mathrm{Q}$. 13, Aver. 2.6). It was not possible to confirm whether the use of power by expatriate executives was coercive or non-coercive.

ii) As to commitment, the results were highly positive for all questions pertinent to this variable. They indicated that both expatriate and local employees sought to establish enduring professional relationships with each other, suggesting that there was a two-way, i.e. collaborative, commitment to their relationships (Q. 14, Av. 3.5;3.1; Q.15 Av. 3.5;3.5). The fact that expatriates were viewed as paying attention to the specific needs of the international subsidiary (Q. 16, Av. 4.2; 3.8) lent additional support to the evidence regarding this commitment.

iii) In the case of the communication variable, the results were also very positive. They strongly suggested that communication, which included the organization of meetings by expatriates to discuss parent company issues (Q 12 - Av. 3.7; 3.1), was carried out frequently (Q 9 - Av. 3.1; 3.5 and Q.10 - Av. 4.1; 3.3) and in a clear and transparent fashion (Q.12 - Av. 3.8; 3.0).

iv) As to the flexibility variable, the results were positive only to a certain extent. Although the respondents agreed that all important decisions that required expatriate approval were taken in an agile manner (Q.20 Av. 3.6; 3.4), they neither agreed nor disagreed that decisions that require the 
Vale parent company's approval were taken in such a manner (Q. 18, Av. 2.6.; 2.5). This was also the case regarding the statement that decisions taken by expatriates were not negotiable (Q.21, Av. $2.4 ; 2.8)$.

v) Where the trust variable was concerned, the results in terms of expatriates' perceptions were positive. Indeed they strongly suggested that from the latter's perspective, there were no big risks that either the Vale parent company or the expatriates would not fulfill agreements with local employees (Q. 28 Av. 2.0 and Q. 29 Av. 1.9) or act opportunistically (Q. 30, Av. 1.9). On the other hand, the perceptions of local executives were neutral regarding questions pertinent to this variable.

vi) With respect to the interdependence variable, the results were all very positive in terms of the perceptions of both populations. They were both of the opinion that the relationship with the international subsidiary was perceived as fundamental to the Vale parent company's success $(\mathrm{Q}$. 22 Av. 4.4; 4.3) and, likewise, albeit not as intensely, that of the subsidiary with the parent company was perceived as fundamental to the subsidiary's success (Q.23, Av. 3.7; 3.8). These results are very relevant, especially in the light of those for Questions 1 and 3 of the first part of the questionnaire. While the latter confirmed the parent company's strategic role in its network of relationships with international subsidiaries, the results pertinent to the interdependence variable reinforced the evidence of the strategic dimension of the relationships in this network.

Question 24 explicitly addresses the issue of the contribution of expatriates who participate in the management of Vale's international subsidiaries to the success of the relationship between Vale and its subsidiaries. Here, too, the results were highly positive (Av. 4.4.; 4.0). Viewed in conjunction with the other results concerning the interdependence variable, they strongly suggested that both populations perceived that the role of expatriate subsidiary executives was critical to the success of the management of the strategic network of relationships between the parent company and its subsidiaries.

vii) As for the cultural integration variable, the results were not conclusive. Although the results suggested that expatriates mapped cultural differences and promoted guidance regarding these differences, at least according to the expatriates' perceptions (Q. 26, Av. 3.0), this was not the case when it came to assessing the Vale parent company's role in this respect (Q. 25, Av. 2.8). Furthermore, the results on the statement that conflicts from cultural differences are frequent were not perceived as significant (Q. 27, Av. 2.6; 2.5) by either expatriates or local managers.

\section{Discussion}

What is striking when analyzing the results presented above is the fact that they reveal positive implications in the case of practically all the variables pertinent to social mechanisms of corporate governance. At the same time, they point towards an active positive role on the part of expatriates where these variables are concerned. They, thus, strongly suggest that the participation of expatriates in the management of Vale's international subsidiaries contributes to corporate governance through informal elements pertinent to social governance mechanisms.

Inasmuch as corporate governance was investigated as a construct of the network management dimension in the SNA model, and in the light of assumption A4, these results lent strong support to our first supposition (S1): the participation of expatriates in the management of Vale's international subsidiaries can be a critical success factor for the corporate governance of the company's network of relationships with these subsidiaries, to the extent that they contribute informal elements concerning the social mechanisms of corporate governance.

On the basis of the perceptions of the expatriates that represented the Vale parent company executives' viewpoint in the study, the results also provided elements to support our second supposition (S2): the Vale parent company perceives that it benefits from the participation of expatriates in the management of its international subsidiaries due to their contribution to the corporate governance of the parent company $\rightarrow$ subsidiary relationship. Indeed, when one considers the highly 
positive results of Question 24 regarding the Interdependence variable, in the light of the positively reinforcing implications of the other network variables for corporate governance, network structure and ties, from the point of view of the Vale parent company expatriates, it becomes evident that the latter recognize the contribution of expatriates in the subsidiaries to the corporate governance of the relationship with them.

Similarly, on the basis of the local executives' perceptions of the aforementioned variables, we found evidence to support our third supposition (S3): the international subsidiaries also perceive that they benefit from the participation of the Vale parent company's expatriates in their management due to their contribution to the corporate governance of the subsidiary $\rightarrow$ parent company relationship.

What is interesting is that the study revealed that this perception was less intense - that is, less positive - than that of the parent company. Indeed, in practically all the results regarding this supposition, the averages for local managers were lower than those for the expatriates. For example, for Questions 22 and 24 related to the Interdependence variable, local managers' averages were slightly lower than those of expatriates (Q.22: Expat Av. 4.4; Local Av. 4.3; Q. 24: Expat Av.: 4.4; Local Av. 4.0). Moreover, in the case of Question 1 regarding the strategic role of the Vale Parent company's participation in the network, the average for expatriates was higher (Q.1 Expat Av. 4.3; Local Av. 3.8).

In an attempt to understand this difference in perception, we reexamined the results for each one of the corporate governance variables. We found that those pertinent to the trust variable were neutral from the local managers' viewpoint (see Loc. Av. for Q. 28, 29 and 30), whereas from the expatriates' perspective they were fairly positive. This result made us wonder whether the local managers had doubts regarding the extent to which they could really trust the Vale parent company and its expatriates in their relationships with the local employees. If this was the case, this could probably explain why, from the viewpoint of the local managers compared with that of the parent company, the benefit referred to in $\mathrm{S} 3$ was considered less positive.

\section{CONCLUSIONS}

At this point, it is important to recall our research question: Is the participation of Vale's expatriates in the management of its international subsidiaries a critical success factor for its corporate governance?

As was shown here, by verifying our three suppositions, the results of our case study at Vale strongly suggested that the expatriates in its international subsidiaries can indeed contribute to the success of its corporate governance through informal elements pertinent to social governance mechanisms inasmuch as these have positive implications for the management of the network of relationships with its subsidiaries. Among these informal elements, commitment, communication, flexibility, trust and interdependence were found to be especially significant, although on the whole their beneficial effect in most cases was perceived to be slightly lower from the subsidiaries' viewpoint compared to that of the parent company.

In this way, the article highlights the critical role of expatriate executives in the success of Vale's corporate governance and thus answers our research question, while attending to our study's specific objectives regarding whether and how expatriate managers in Vale's international subsidiaries contribute to its corporate governance.

By lending empirical support to research findings regarding the importance of complementing the use of formal corporate governance methods with informal ones, concerning social governance mechanisms, the article adds value to the debate on the role of expatriates in the management of subsidiaries and their contribution to the corporate governance of international firms. 
Where business practitioners are concerned, the article provides insights for the top management of firms by showing how appointing executives to international positions can be important for the company. It indeed becomes obvious that managers of international firms must pay more attention to social mechanisms of corporate governance and help develop the competencies for exercising such mechanisms as a network management tool. The research moreover provided some indicators for measuring social mechanisms that can be useful for enhancing effective network management.

In addition, for academia these indicators contribute to the development of a more robust social corporate governance construct, making it possible to assess the positive and negative implications of each one of the variables associated with this construct.

As to future research, we highly recommend that our investigation at Vale from a network perspective be replicated in other firms with international subsidiaries, following the same case study protocol, but with a much deeper analysis of each firm in the network focused on. The objective would be to verify to what extent our suppositions continue to be valid in spite of differences regarding the respective parent firm and subsidiary characteristics in the light of the argument of Kim et al. (2005) on the latter. Such an analysis should include in-depth interviews also to understand better the viewpoint of local managers in the international subsidiaries regarding complex questions such as those concerning trust and cultural integration variables and their implications for the perception of the beneficial effects of expatriate executives in these subsidiaries.

Studies of the social corporate governance mechanisms used in the strategic management of networks of international relationships are still few and far between. Therefore, there are vast opportunities for fresh contributions to research on this topic through pertinent investigations from a strategic network perspective of firms from different sectors that operate in the current context of growing internationalization.

\section{NOTE}

${ }^{1}$ A preliminary version of this paper was presented at the EIBA Conference 2008, Tallinn, Estonia.

\section{REFERENCES}

Bachmann, R. (2001). Trust, power and control in trans-organizational relations. Organization Studies, $22(2), 337-365$.

Bantham, J. H., Celuch, K. G., \& Kasouf, C. J. (2003). A perspective of partnerships based on interdependence and dialectical theory. Journal of Business Research, 56(4), 265-274.

Bjorkman, I. (2004). Managing knowledge transfer in MNCs. Journal of International Business Studies, 35(5), 443-455.

Boyacigiller, N. (1990). The role of expatriates in the management of interdependence, complexity and risk in multinational corporations. Journal of International Business Studies, 21(3), 357380 .

Bueno, J. M. (2004). O processo de expatriação como instrumento de integração de culturas em uma organização no Brasil - o caso Renault. Masters dissertation, Pontifícia Universidade Católica do Paraná, Curitiba, PR, Brazil. 
Chiles, T. H., \& McMackin, J. F. (1996). Integrating variable risk preferences, trust, and transaction cost economics. The Academy of Management Review, 21(1), 73-99.

Clarke, C. C., \& Lipp, G. D. (1998). Conflict resolution for contrasting cultures. Training and Development, 52(2), 20-33.

Companhia Vale do Rio Doce. (2005). Relatório anual 2005. Retrieved May 10, 2007, from http://www.vale.com/vale/media/CVRD_RA_2005.pdf

Companhia Vale do Rio Doce. (2009). Estatuto social da CVRD. Retrieved June 6, 2009, from http://www.vale.com/vale/media/090522Estatutop.pdf

Cornelius, P. (2005). Good corporate practices in poor corporate governance systems: some evidence from the global competitiveness report. Corporate Governance, 5(3), 12-23.

Costa, A. C. (2007). Trust and control interrelations. Group and Organization Management, 32(4), 392-406.

Dickson, M. A., \& Zhang, L. (2004). Supplier-retailer relationships in China's distribution channel for foreign brand apparel. Journal of Fashion Marketing and Management, 8(2), 201-216.

Edström, A., \& Galbraith, J. R. (1977). Transfer of managers as a coordination and control strategy in multinational organizations. Administrative Science Quarterly, 22(2), 249-263.

Fenwick, M. S., De Cieri, H., \& Welch, D. (1999). Cultural and bureaucratic control in MNEs: the role of expatriate performance management. Management International Review, 39(3), 107-124.

Galaskiewicz, J., \& Zaheer, A. (1999). Networks of competitive advantage. In S. Andrews \& D. Knoke (Orgs.). Research in the sociology of organizations (pp. 237-261). Greenwich, CT: Jai Press.

Gao, T., Bao, Y., \& Wang, Y. (2002, Summer). Plural governance forms for international strategic alliances: an integrative framework. American Marketing Association. Conference Proceedings, San Diego, CA, 13.

Gulati, R., Nohria, N., \& Zaheer, A. (2000). Strategic networks. Strategic Management Journal, 21(3), 203-215.

Halinen, A., \& Törnroos, J. (2005). Using case methods in the study of contemporary business networks. Journal of Business Research, 58(9), 1285-1297.

Harzing, A. W. K. (2001). Of bears, bumble-bees and spiders: the role of expatriates in controlling foreign subsidiaries. Journal of World Business, 36(4), 366-379.

Heide, J. B., \& Miner, A. S. (1992). The shadow of the future. Academy of Management Journal, 35(2), 265-291.

Hunt, S. D., \& Morgan, R. M. (1994). Organizational commitments: one of many commitments or key mediating constructs? The Academy of Management Journal, 37(6), 1568-1587.

Kauser, S., \& Shaw, V. (2004). The influence of behavioural and organizational characteristics on the success of international strategic alliances. International Marketing Review, 21(1), 17-52.

Kim, B., Prescott, J. E., \& Kim, S. M. (2005). Differentiated governance of foreign subsidiaries in transnational corporations: an agency theory perspective. Journal of International Management, 11(1), 43-66.

Kotha, S., \& Vadlamani, B. L. (1995). Assessing generic strategies. Strategic Management Journal, 16(1), 75-83. 
Lee, J. Y., \& MacMillan, I. C. (2008). Managerial knowledge-sharing in chaebols and its impact on the performance of their foreign subsidiaries. International Business Review, 17(5), 533-545.

Lï, J. (2001). Network development for competitive advantage: a study of subsidiary networks and alliance networks. Doctoral dissertation, Richard Ivey School of Business, University of Western Ontario, London, Ontario, Canada.

Macedo-Soares, T. D. L. v. A. de (2002, June). Strategic alliances and networks: conceptual tools for strategic assessments. Readings Book of Global Business And Technology Association Forth International Conference, Rome, Italy.

Macedo-Soares, T. D. L. v. A. de, \& Figueira, L. A. (2007). Gestão estratégica da energia nucleoelectrica no Brasil. Revista de Administração Contemporânea, 11(1a Edição Especial), $55-76$.

Macedo-Soares, T. D. L. v. A. de, Tauhata, T. L., \& Freitas, J. C. T. (2004). Strategic implications of alliances and networks of horizontal portals in Brazil. Latin American Business Review, 5(2), 71-102.

Macedo-Soares, T. D. L. v. A. de, Tauhata, T., \& Lima, F. C. de (2005). Implicaciones estratégicas de las redes de alianzas en el sector de lineas aereas. Revista de Empresa, (13), 56-76.

McClave, J. T., Benson, P. G., \& Sincich, T. (2001). Statistics for business and economics. Upper Saddle River, NJ: Prentice Hall.

Meschi, P. (1997). Longevity and cultural differences of international joint ventures. Human Relations, 50(2), 211-228.

Minbaeva, D. B., \& Michailova, S. (2004). Knowledge transfer and expatriation in multinational corporations: the role of disseminative capacity. Employee Relations, 26(6), 663-679.

Moraes, M. N. (2005). Governança corporativa: fator crítico de sucesso na gestão estratégica de empresas em alianças. Masters dissertation, Pontifícia Universidade Católica do Rio de Janeiro, Rio de Janeiro, RJ, Brazil.

Patton, M. Q. (1987). How to use qualitative methods in evaluation. Newbury Park, CA: Sage

Prater, E., Biehl, M., \& Smith, M. A. (2001). International supply chain agility. International Journal of Operations \& Production Management, 21(5), 823-839.

Rea, L. M., \& Parker, R. A. (1997). Designing and conducting survey research: a comprehensive guide (2nd ed.). San Francisco, CA: Jossey-Bass.

Riusala, K., \& Suutari, V. (2004). International knowledge transfers through expatriates. Thunderbird Int. Business Review, 46(6), 743-770.

Rodriguez, C. M. (2005). Emergence of a third culture. International Marketing Review, 22(1) 67-95.

Segil, L. (1998). Strategic alliances of the $21^{\text {st }}$ century. Strategy \& Leadership, 26(4), 12-16.

Strikwerda, J. (2003). An entrepreneurial model of corporate governance. Corporate Governance, $3(2), 38-57$.

Volkmar, J. A. (2003). Context and control in foreign subsidiaries Making. Journal of Leadership \& Organizational Studies, 10(1), 93-105.

Wagner, B. A., Macbeth, D. K., \& Boddy, D. (2002). Improving supply chain relations. Supply Chain Management, 7(3), 253-264. 
Weber, R. P. (1990). Basic Content Analysis. London: Sage University Papers.

Yin, R. K. (2003). Case study research: design and methods (3rd ed.). Thousand Oaks, CA: Sage. 